\title{
Conjunctival Melanoma cM0 TNM Finding v8
}

National Cancer Institute

\section{Source}

National Cancer Institute. Conjunctival Melanoma cMO TNM Finding v8. NCI Thesaurus. Code C140559.

Conjunctival melanoma with no distant metastasis. (from AJCC 8th Ed.) 